\title{
Analysis of Circulating Tumor Cells in Ovarian Cancer and Their Clinical Value as a Biomarker
}

\author{
Xuehui Zhang ${ }^{a}$ Hui Lia Xiuyan Yu ${ }^{a}$ Shanxin Lia Zhen Lei ${ }^{\mathrm{e}}$ Chang Li ${ }^{\mathrm{a}}$ \\ Qun Zhang ${ }^{a}$ Qing Han ${ }^{a}$ Yuan Lib Kun Zhang ${ }^{b}$ Yuxiang Wang ${ }^{c}$ \\ Congrong Liuc Yiqing Mao ${ }^{\mathrm{a}}$ Xi Wang ${ }^{\mathrm{a}}$ David M. Irwin ${ }^{\mathrm{d}}$ Hongyan Guo ${ }^{\mathrm{b}}$ \\ Gang Niue Huanran Tan ${ }^{\mathrm{a}}$
}

aDepartment of Pharmacology, School of Basic Medical Sciences, Peking University Health Science Center, Beijing, 'Department of Obstetrics and Gynecology, Peking University Third Hospital, Beijing, 'Department of Pathology, School of Basic Medical Science, Peking University Third Hospital, Peking University Health Science Center, Beijing, P.R. China, dDepartment of Laboratory Medicine and Pathobiology, University of Toronto, Toronto, Canada, eBeijing N\&N Genetech Company, Beijing, China

\section{Key Words}

Ovarian cancer • Circulating tumor cells • Diagnose • Prognosis • Treatment monitor

\begin{abstract}
Background/Aims: Monitoring the appearance and progression of tumors are important for improving the survival rate of patients with ovarian cancer. This study aims to examine circulating tumor cells (CTCS) in epithelial ovarian cancer (EOC) patients to evaluate their clinical significance in comparison to the existing biomarker CA125. Methods: Immuomagnetic bead screening, targeting epithelial antigens on ovarian cancer cells, combined with multiplex reverse transcriptase-polymerase chain reaction (Multiplex RT-PCR) was used to detect CTCs in 211 samples of peripheral blood $(5 \mathrm{ml})$ from 109 EOC patients. CTCs and CA125 were measured in serial from 153 blood and 153 serum samples from 51 patients and correlations with treatment were analyzed. Immunohistochemistry was used to detect the expression of tumor-associated proteins in tumor tissues and compared with gene expression in CTCs from patients. Results: CTCs were detected in 90\% (98/109) of newly diagnosed patients. In newly diagnosed patients, the number of CTCs was correlated with stage $(p=0.034)$. Patients with stage IA-IB disease had a CTC positive rate of 93\% (13/14), much higher than the CA125 positive rate of only $64 \%(9 / 14)$ for the same patients. The numbers of CTCs changed with treatment, and the expression of EpCAM $(p=0.003)$ and HER2 $(p=0.035)$ in CTCs was correlated with resistance to chemotherapy. Expression of EpCAM in CTCs before treatment was also correlated with overall survival (OS) $(p=0.041)$. Conclusion: Detection of CTCs allows early diagnose and expression of EPCAM in CTC positive patients predicts prognosis and should be helpful for monitoring treatment.

D.M. Irwin, H. Guo, G. Niu and H. Tan contributed equally to this work.




\section{Introduction}

Ovarian cancer is the 3th most common and the most lethal cause of gynecologic malignancy [1]. In China, approximately 52, 100 cases, and 22, 500 deaths, occurred in 2015 [2]. A reason why ovarian cancer has become a major threat to the health of women lies in its "occult" nature, where about $75 \%$ of the patients are only diagnosed at an advanced stage [3]. Resistance to chemotherapy after treatment is also a major cause of recurrence and death $[4,5]$. Combined, these result in a 5-year survival rate of less than $30 \%$. Early diagnosis of ovarian cancer and improved chemotherapeutic treatments can potentially increase the survival and cure rates for this disease [6]. Currently CA125 is the most frequently used biomarker for ovarian cancer, but it has a low detection rate for early diagnosis and has limited specificity [7], thus new markers are urgently needed.

"Liquid biopsy" [8], where body fluids (e.g., blood) is screened for biomarkers such as circulating tumor cells (CTCs), circulating free DNA, or exosomes [9], has attracted extensive attention due to its advantages such as ease of obtaining samples, being less invasive, and being easy to track. Circulating tumor cells, which are cells shed into the bloodstream from primary tumors, recurrences, or metastases, and possess tumor-specific characteristics [10], are good targets for liquid biopsy. CTCs are considered to be an origin for metastases $[11,12]$, and their presence has been reported for several cancers, including breast, lung, liver, and prostate cancer [13-17]. Recently, some researchers have reported detection rates of between $12 \%$ and $90 \%$ for EOC CTCs using different methods, including the CellSearch ${ }^{\mathrm{TM}}$ System (Veridex, Raritan, NJ), density-gradient separation followed by immunostaining of cytokeratin, and density-gradient separation combined with RT-PCR [18-20]. However, the detection rate of CTCs in early stage disease cases is generally low, and the conclusions have been controversial, thus new methods to detect EOC CTCs are still needed. If CTCs could be efficiently detected in the blood of EOC patients, this should assist not only in the diagnosis of this cancer, but also our understanding of the dynamic progress of EOC disease and thus, support the development of new precise clinical schemes for treatment.

Here we used monoclonal antibodies specific for the epithelial markers EpCAM [21], HER2 [22], and MUC1 [23] to isolate CTCs from the peripheral blood of EOC patients [24]. Isolated CTCs were then examined by Multiplex RT-PCR for the expression of six genes (EpCAM, HER2, MUC1, WT1, P16, and PAX8) that are associated with ovarian cancer [25-28]. We compared our detection results with clinical classification data, including clinical type, stage, and prognosis, and examined the levels of CTCs before or after treatment to determine the effectiveness of using CTCs as a biomarker for the diagnosis, predicting prognosis, and monitoring of treatment.

\section{Materials and Methods}

\section{Sample collection}

The ethics review board of the Departments of Gynecology and Pathology, Peking University Third Hospital, approved this study. All patients gave written informed consent before participation. The study group consisted of 109 EOC patients and 30 healthy women volunteers. The mean age of the patients was 54 years (range: 24-77 years). Among the patients, 28 "occult" EOC patients were found during physical examinations, with the remaining patients displaying typical EOC symptoms including abdominal pain, abdominal distension, and abnormal vaginal bleeding. Of the 109 patients, 31 accepted treatment by non-neoadjuvant chemotherapy (chemotherapy after operation) and 20, with a wide range of tumor foci, accepted treatment of neoadjuvant chemotherapy (operation after chemotherapy). All of these 51 patients had their CTC and CA125 levels measured three times. CTCs were assayed in the 31 non-neoadjuvant chemotherapy patients as follows: prior to surgery, 7-14 days after surgery, and then after three cycles of postoperative chemotherapy. CTC assays in the 20 neoadjuvant chemotherapy patients were as follows: 


\section{Cellular Physiology Cell Physiol Biochem 2018;48:1983-1994

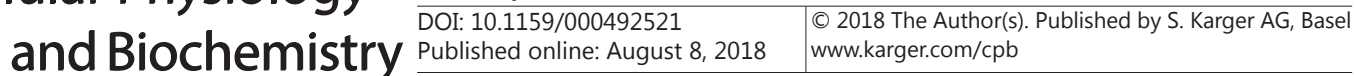

Zhang et al.: CTCs as a Biomarker in Ovarian Cancer

prior to chemotherapy, after three cycles of chemotherapy but before surgery, and then 7-14 days after surgery. Serum CA125 levels were also analyzed at these same times, and results $\geq 35 \mathrm{U} / \mathrm{ml}$ were considered to be positive. Blood samples $(5 \mathrm{ml})$ were dawn in Vacuette EDTA tubes (BD Biosciences), stored at $4^{\circ} \mathrm{C}$, and processed within 24h. Patients were followed for up to 48 months (range: 1-48 months). Pathological characteristics of the tumors were classified according to the WHO standard, the stage based FIGO standard, and the grade based on the Silverberg standard [29]. Patients displaying recurrence within 6 months of complete treatment were considered to be chemotherapy resistant.

Screening tumor cells in the peripheral blood of patients with epithelial ovarian cancer

Magnetic powder (Dynabeads M-450 Tosylactivated, Invitrogen, USA) labeled monoclonal antibodies (Abcam, England) for the epithelial markers EpCAM, HER2, and MUC1 were prepared according to the manufacturer's manual. Briefly, the three magnetic powder bead-labeled monoclonal antibodies, in a proportion of $1: 1: 1$, in a volume of $125 \mathrm{ul}$ were added to $5 \mathrm{ml}$ blood and incubated at $4^{\circ} \mathrm{C}$ for $30 \mathrm{~min}$. Beads were then washed three time with buffer solution, and cells collected with a magnet after mixing (Invitrogen, USA). Cell contents were released using 200ul of lysis buffer (from Dynabeads mRNA DIRECT Kit, Invitrogen, USA), and mRNA was isolated according to the Dynabeads mRNA DIRECT Kit, then reverse transcribed into cDNA using the Sensitive Reverse Transcription Kit (Qiagen, Germany).

Expression of ovarian cancer related genes in CTCS

Expression of 6 ovarian cancer related genes was detected in CTCs from EOC patients using Multiplex RT-PCR, with primers for EpCAM (forward: 5'-TGAGCGAGTGAGAACCTA-3'; reverse: 5'-CACAACAATTCCAGCAAC-3'), HER2 (forward: 5'-AGGAGTGCGTGGAGGAAT-3'; reverse: 5'-AGTGGGTGCAGTTGATGG-3'), and MUC1 (forward: 5'-GCACCGACTACTACCAAGAG-3'; reverse: 5'-AAGGAAATGGCACATCACT-3') in one group, and the primers for WT1 (forward: 5'-AGTCCGCCATCACAACAT-3'; reverse: 5'-TGGTACAATAATTCCATCCC-3'), P16 (forward: 5'-TCTGAGAAACCTCGGGAAAC-3'; reverse: 5'-CTCGCAAGAAATGCCCAC-3'), and PAX8 (forward: 5'-GAAGCAATAGCCGAGGAA-3'; reverse: 5'-TGTAGAAAGAGCCAAGCAAA-3') in a second group. Actin (forward: 5'-GAAATCGTGCGTGACATTA-3'; Reverse: 5'-AGGCAGCTCGTAGCTCTT-3') was used as the reference gene. PCR conditions were: $95^{\circ} \mathrm{C}$ for $15 \mathrm{~min}$, followed by $94^{\circ} \mathrm{C}$ for $30 \mathrm{~s}, 58^{\circ} \mathrm{C}$ for $90 \mathrm{~s}$, and $72^{\circ} \mathrm{C}$ for 60 s, for 35 cycles followed by $60^{\circ} \mathrm{C}$ for $30 \mathrm{~min}$. PCR products were visualized using Agilent 2100 Bioanalyzer (Agilent Technologies, USA) with DNA 1000 LabChips (Agilent Technologies USA) for qualitative and quantitative analysis. Product concentrations higher than $0.3 \mathrm{ng} / \mu \mathrm{l}$ for any the 6 genes (EpCAM, HER2, MUC1, WT1, P16, and PAX8) was judged as being positive for the presence of CTCs. The cutoff value was set as 3 times the average value of the PCR concentration of the 6 genes expressed in the blood of healthy volunteers.

\section{Sensitivity and standard curve for the detection of ovarian cancer related gene transcripts}

Ovarian cancer cell line SKOV3 (ATCC, grown in DMEM + 5\% FBS, 5\% CO2, 37 ${ }^{\circ} \mathrm{C}$ ) was used as a positive control. SKOV3 cells were diluted to concentrations of $0,2,5,10,50$, and 100 cells in $5 \mathrm{ml}$ peripheral blood from healthy volunteers, in accordance to the method for magnetic screening combined with multiplex RTPCR detection. This experiment was repeated 10 times.

\section{Immunohistochemical analysis of WT1 and PAX8 expression}

Representative haematoxylin-eosin stained slides from the tumors were reviewed, and one representative block was selected for IHC. Immunohistochemical analyses were performed on formalin fixed, paraffin embedded, $4 \mu \mathrm{m}$ thick tissue sections. The primary antibodies used were anti-PAX8 and anti-WT1 rabbit monoclonal antibody (mAb) (Zeta, Corporation, California, USA) and pAb (Protein Tech Group, Chicago, Illinois, USA). Tissue sections were deparaffinised and rehydrated through xylene and graded ethanol solutions to water. Antigen retrieval was performed using pressure cooker pretreatment in Tris EDTA buffer (pH 9.0) for 2 min. After blocking the endogenous peroxidase activity with 3\% hydrogen peroxidase for $10 \mathrm{~min}$, sections were incubated with primary antibody (mAb, dilution: 1:100; pAb, dilution: 1:100) overnight at $4^{\circ} \mathrm{C}$. Detection reactions utilized the Envision kit from Dako (DakoCytomation, Glostrup, Denmark). Diaminobenzidine was used as the chromogen and haematoxylin as the counterstain. Appropriate positive (serous ovarian carcinoma tissue) and negative (incubation with Tris buffered saline instead of the specific primary antibody) controls were run simultaneously. Analyses of IHC results were performed by 
two independent authors (XZ and YW). Discrepancies in the analyses were reconciled following a review by a third reviewer (CL). Nuclear staining in more than $5 \%$ of the malignant cells was considered as positive. For positive cases, staining intensity was further scored as follows: 0 , no staining; 1 , unequivocal but weak intensity; 2 , moderate intensity; and 3, marked intensity.

\section{Statistical analysis \\ Clinical EOC samples} were classified based on stage, grade, treatment status, and chemotherapy resistance and compared to the detection of CTCs using one-way ANOVA. Survival rate and progression free survival curves were calculated for each group with Kaplan-Meier estimates and compared with the Log-rank test. $\mathrm{P}<0.05$ was considered to be significant. All statistical analyses were performed using SPSS 22 software.
Table 1. Clinical characteristics of the patients. NOTE: N1, patients had lymph node metastasis; N0, patients had no lymph node metastasis

\begin{tabular}{|c|c|c|c|c|c|c|}
\hline & \multicolumn{2}{|c|}{ Newly diagnosed; $n=109$} & \multicolumn{4}{|c|}{ After treatment; $n=102$} \\
\hline & $\begin{array}{c}\text { CTC positive } \\
\mathrm{n}=98\end{array}$ & $\begin{array}{c}\text { CTC negative } \\
n=11\end{array}$ & $\begin{array}{c}P \\
\text { value }\end{array}$ & $\begin{array}{c}\text { CTC positive } \\
n=93\end{array}$ & $\begin{array}{c}\text { CTC negative } \\
n=9\end{array}$ & $P$ value \\
\hline Age Average & 53 & 53 & 0.46 & 53 & 53 & \multirow{2}{*}{0.275} \\
\hline $\begin{array}{l}\text { Age Range } \\
\text { Symptom }\end{array}$ & $28-77$ & $32-62$ & 8 & $28-75$ & $47-62$ & \\
\hline Yes & 71 & 10 & \multirow{2}{*}{0.184} & $\mathrm{~N}$ & $\mathrm{~N}$ & \multirow{3}{*}{$\mathrm{N}$} \\
\hline $\begin{array}{l}\text { No } \\
\text { CA125 }\end{array}$ & 27 & 1 & & $\mathrm{~N}$ & $\mathrm{~N}$ & \\
\hline$\geq 35 \mathrm{U} / \mathrm{ml}$ & 90 & 10 & \multirow{3}{*}{0.838} & 57 & 3 & \\
\hline$<35 \mathrm{U} / \mathrm{ml}$ & 8 & 1 & & 36 & 6 & \multirow{2}{*}{0.104} \\
\hline Stage I & 19 & 4 & & 19 & 1 & \\
\hline Stage II & 11 & 2 & \multirow{3}{*}{0.331} & 8 & 1 & \multirow{3}{*}{0.879} \\
\hline Stage III & 53 & 5 & & 52 & 6 & \\
\hline Stage IV & 15 & 0 & & 14 & 1 & \\
\hline Tumor size & & & & & & \\
\hline$<5 \mathrm{~cm}$ & 6 & 0 & \multirow{3}{*}{0.399} & 93 & 9 & \multirow{3}{*}{$\mathrm{N}$} \\
\hline$\geq 5 \mathrm{~cm}$ & 92 & 11 & & 0 & 0 & \\
\hline Histology & & & & & & \\
\hline Serous & 85 & 6 & \multirow{6}{*}{0.097} & 81 & 7 & \\
\hline Mucinous & 4 & 1 & & 5 & 0 & \multirow{5}{*}{0.169} \\
\hline Endometrioid & 1 & 1 & & 0 & 0 & \\
\hline Clear cell & 6 & 3 & & 6 & 1 & \\
\hline Others & 2 & 0 & & 1 & 1 & \\
\hline Grade1 & 7 & 2 & & 3 & 0 & \\
\hline Grade2 & 7 & 0 & \multirow[t]{3}{*}{0.323} & 6 & 0 & \multirow[t]{3}{*}{0.62} \\
\hline Grade3 & 84 & 9 & & 84 & 9 & \\
\hline Lymph node & & & & & & \\
\hline N1 & 25 & 3 & \multirow[t]{2}{*}{0.899} & 3 & 1 & \multirow{2}{*}{0.245} \\
\hline N0 & 73 & 8 & & 90 & 8 & \\
\hline
\end{tabular}

\section{Results}

\section{Detection of CTCS and correlation with clinical characteristics}

We first established our experimental method and tested its sensitivity using diluted SKOV3 in blood. As shown in Fig. 1A, the sensitivity of our method is $\geq 2 \mathrm{CTCs} / 5 \mathrm{ml}$ and a standard curve for cell number and PCR product concentrations was established (Fig. 1B). CTCs were detected in 191 of the 211 (91\%) blood samples (Fig. 1A). CTCs were not detected in any healthy volunteers. The CTC detection rate in newly diagnosed patients was $90 \%$ (98/109), while for patients receiving treatment it was $91 \%(93 / 102)$, with average CTCs numbers of 264 (range 0-1929) and 314 (range 0-1822) per $5 \mathrm{ml}$ blood, respectively (Table 1). In the 109 newly diagnosed EOC patients, CTCs were detected in 82\% (19/23), $85 \%(11 / 13), 91 \%$ (53/58), and 100\% (15/15) of cases at stages I, II, III, and IV, respectively. The number of CTCs found in stage I patients was significantly lower than for patients with stage III ( $\mathrm{p}=0.015)$ or IV ( $\mathrm{p}=0.01)$ disease (Fig. $2 \mathrm{~A}$ and $\mathrm{B}$, and Table 2$)$. CA125 was detected in $65 \%(15 / 23), 100 \%(13 / 13), 100 \%$ (58/58), and 93\% (14/15) of cases at stages I, II, III, and IV, respectively, but no correlation was found between the CA125 levels and cancer stages ( $\mathrm{p}=0.1$ ) (Fig. 2C and D).

Among the 36 patients with early stage (I and II) disease, 14 were "occult" patients that did not display typical EOC symptoms. For these patients, the CTCs positive rate was $93 \%(13 / 14)$, while $86 \%(12 / 14)$ of them were CA125 positive. A larger difference in the detection rates with CTCs and CA125 was seen for stage IA-IB patients, where 93\% (13/14) were positive for CTCs but only 64\% (9/14) were positive for CA125 (Fig. 2E). Of the stage IA-IB patients, the CTC positive rate for the 7 "occult" patients was $100 \%(7 / 7)$, while only 57\% (4/7) were CA125 positive (Fig. 2F). We also analyzed the correlation between CTC or CA125 levels and other clinical features, such as grade and pathological type, but no significant correlations were found (Table 1). Detection of CTC was not correlated with CA125 levels after treatment $(\mathrm{p}=0.104)$ (Table 1). 
Treatment monitoring of patients using CTCs and CA125

In the 31 patients that accepted non-neoadjuvant chemotherapy, the CTC detection rates were $84 \%$, $90 \%$, and $100 \%$ for the first, second, and third sampling time points, respectively. The numbers of CTCs increased significantly after surgery $(\mathrm{p}=0.023)$, and then decreased $(\mathrm{p}=0.272)$ after 3 cycles of chemotherapy (Fig. 3A). In contrast, CA125 positive rates were $90 \%, 77 \%$, and $55 \%$, for these three time points, and the concentration of CA125 did not significantly decline $(\mathrm{p}=0.156)$ after treatment (Fig. 3B). In the 20 patients that accepted neoadjuvant chemotherapy, the CTC detection rates were $90 \%$, $85 \%$, and $90 \%$ for the three sampling time points, and the numbers of CTCs decreased after chemotherapy $(\mathrm{p}=0.271)$ but increased significantly after surgery ( $\mathrm{p}=0.017)$ (Fig. 3C). CA125 positive rates were $100 \%, 50 \%$, and $45 \%$ for the three sampling time points, and its concentration declined after treatment $(\mathrm{p}=0.001)$ (Fig. 3D). We also analyzed the mRNA expression levels of 6 ovarian cancer related genes in CTCs but found no relationship with treatment.

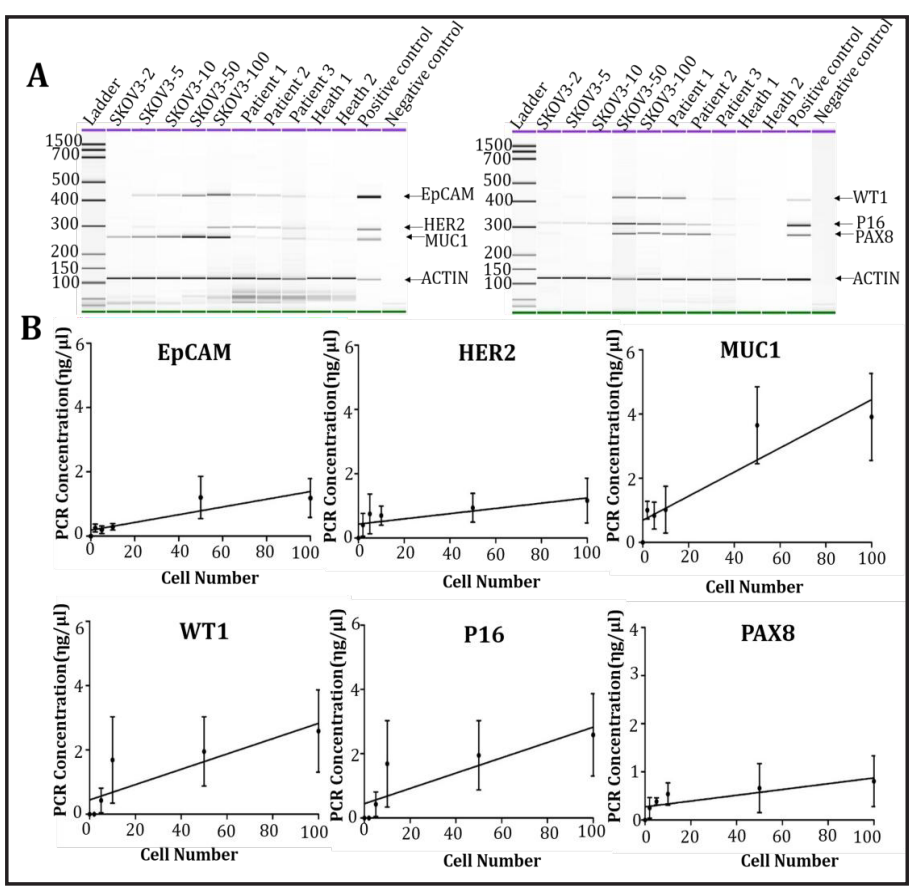

Fig. 1. Immuomagnetic bead screening combined with Multiplex RTPCR to detect CTCs and standard curves for PCR concentrations and cell numbers. A: Sensitivity and specificity of the method. First lane in both gels is the DNA size standard (Ladder). Lanes labeled SKOV3$2,-5,-10,-50$, and -100 are multiplex RT-PCR results from $5 \mathrm{ml}$ of peripheral blood from healthy volunteers containing 2, 5, 10, 50, or 100 SKOV3 cells. Patient 1, Patient 2, and Patient 3 are EOC patients. Health 1 and 2 are control healthy individuals. The positive control is SKOV3 cells, while the negative control is $\mathrm{ddH}_{2} 0$. B: PCR product concentrations and cell numbers: Cell numbers $/ 5 \mathrm{ml}=72.619 *$ PCR concentration of EpCAM)-12.124, $\mathrm{R}^{2}=0.8078$; Cell numbers $/ 5 \mathrm{ml}$ $=133.72 *\left(P C R\right.$ concentration of HER2) $-72.746, R^{2}=0.8114$; Cell numbers $/ 5 \mathrm{ml}=25.11^{*}$ (PCR concentration of MUC1) $-18.909, \mathrm{R}^{2}=$ 0.8606; Cell numbers $/ 5 \mathrm{ml}=32.762^{*}$ (PCR concentration of WT1) $-10.184, \mathrm{R}^{2}=0.7102$; Cell numbers $/ 5 \mathrm{ml}=22.832 *$ (PCR concentration of P16) -12.122, $\mathrm{R}^{2}=0.8326$; Cell numbers $/ 5 \mathrm{ml}=173.17^{*}$ (PCR concentration of PAX8) $-58.378, \mathrm{R}^{2}=0.8144$. The number of cells was obtained from the standard curve for the six genes, where the largest number was defined as the number of CTCs in a patient.

Table 2. Numbers of CTCs and the relative mRNA levels of EOC-related genes in CTCs from different stages of EOC (mean \pm SD)

\begin{tabular}{lccccccc}
\hline \multirow{2}{*}{ Stage } & Cell & & & \multicolumn{4}{c}{ Gene (relative expression) } \\
& numbers $/ 5 \mathrm{ml}$ & EpCam & HER2 & MUC1 & WT1 & P16 & PAX8 \\
\hline I & $92 \pm 106$ & $0.096 \pm 0.139$ & $0.126 \pm 0.126$ & $0.115 \pm 0.14$ & $0.232 \pm 0.375$ & $0.122 \pm 0.147$ & $0.225 \pm 0.3$ \\
II & $200 \pm 177$ & $0.086 \pm 0.148$ & $0.087 \pm 0.124$ & $0.043 \pm 0.052$ & $0.335 \pm 0.388$ & $0.173 \pm 0.187$ & $0.364 \pm 0.311$ \\
III & $320 \pm 428$ & $0.266 \pm 0.483$ & $0.304 \pm 0.5$ & $0.329 \pm 0.591$ & $0.378 \pm 0.628$ & $0.244 \pm 0.405$ & $0.42 \pm 0.592$ \\
IV & $400 \pm 425$ & $0.171 \pm 0.374$ & $0.26 \pm 0.272$ & $0.202 \pm 0.276$ & $0.291 \pm 0.387$ & $0.126 \pm 0.157$ & $0.38 \pm 0.48$ \\
\hline
\end{tabular}

\section{KARGER}


Fig. 2. Detection of CTC and CA125 in ovarian cancer patients. A: Detection rate of CTCs in patients with different stages of cancer. B: Average numbers of CTCs in patents with different stages of cancer; C: Detection rate of CA125 in patients with different stages of cancer; D: Average level of CA125 in patents with different stages of cancer E: Detection of CTCs in stage IA- IB patients; F: Detection of CTCs in stage IA-IB patients that did not display typical EOC symptoms.

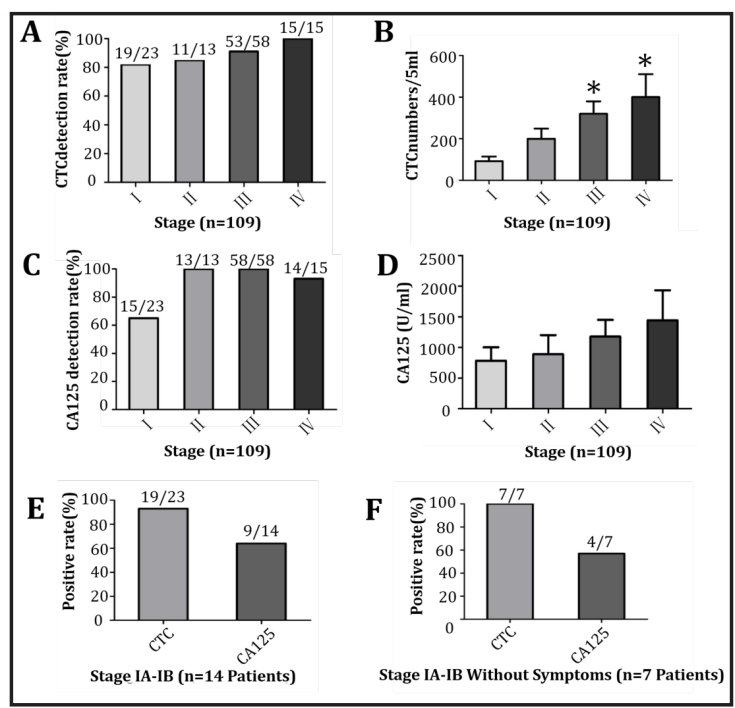

Fig. 3. Correlation of CTC numbers and serum CA125 levels and the monitoring of treatment. A: The numbers of CTCs changed with treatment in 31 non-neoadjuvant treated EOC patients; B: Concentration of serum CA125 changed with nonneoadjuvant treatment of 31 EOC patients; C: The numbers of CTCs changed with treatment in the 20 neoadjuvant treated patients; D: Concentration of serum CA125 changed with treatment in the 20 neoadjuvant treated EOC patients; E: Concentration of serum CA125 from chemotherapy resistant and sensitive patients; F: Expression of EOC-related genes in CTCs from chemotherapy resistant and sensitive patients.

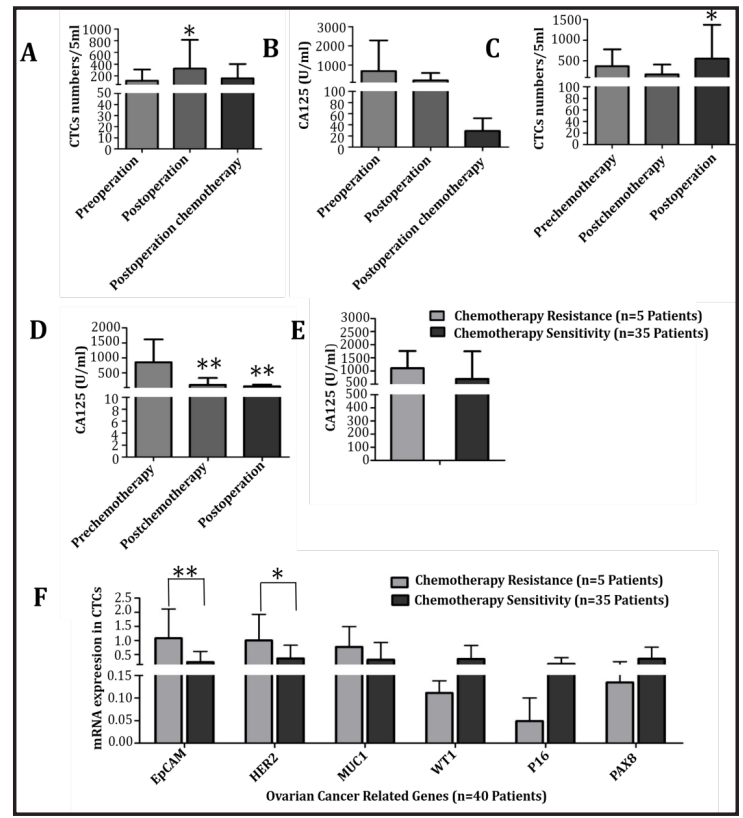

Complete follow-up of more than 6 months after treatment was available for 40 patients ( 9 patients were stage I, 3 patients were stage II, 23 patients were stage III, and 5 patients were stage IV, with 32 of the 40 patients accepting non-neoadjuvant chemotherapy and 8 patients accepting neoadjuvant chemotherapy). Of these patients, 5 displayed resistance to chemotherapy, while the remaining 35 patients were chemosensitive. CTCs were detected in $100 \%(5 / 5)$ of the chemotherapy resistant patients, but only $91 \%(32 / 35)$ of the chemosensitive patients. Statistically significant increased levels of EpCAM ( $p=0.003<0.05)$ and HER2 $(p=0.035<0.05)$ mRNA levels were found in the chemoresistant compared to the chemotherapy sensitive patients (Fig. 3F). No significant differences in the mRNA abundance of MUC1 ( $\mathrm{p}=0.184>0.05)$, WT1 ( $\mathrm{p}=0.343>0.05)$, P16 ( $\mathrm{p}=0.309>0.05)$, or PAX8 ( $\mathrm{p}=0.309>$ $0.05)$ was found between the two groups. We then analyzed CA125 levels between the two group but found no difference ( $p=0.403>0.05$ ) (Fig. 3E). 
Correlation of CTCs with clinical prognosis

In the 62 cases of patients with follow-up, 6 died during the follow-up period, with survival times between 8 and 26 months. CTCs were detected in $100 \%(6 / 6)$ of the patients that died, but only $95 \%(53 / 56)$ in those who survived. When the gene expression profiles of EOC-related genes in the survival and death groups were analyzed, significantly higher levels of EpCAM ( $p=0.001)$ and HER2 ( $p=0.023$ ) mRNA levels were found in the patients who died compared to the survivors (Fig. 4A). No significant difference in the abundance of MUC1 $(p=0.171), \quad$ WT1 $(\mathrm{p}=0.409), P 16(\mathrm{p}=0.631)$, or PAX8 ( $p=0.440)$ mRNA was seen between the two groups, nor was CA125 different between the two groups (Fig. 3B). We found that OS was significantly shorter in the 36 patients with CTCs positive for EpCAM expression compared to the 26 EpCAM negative patients $(\mathrm{p}=0.041<0.05)$ (Fig. $4 \mathrm{C})$. No significant correlation between OS and PFS with any of the other genes and CTCs numbers was found. We then analyzed the relationship between CA125 with PFS and OS and found no significant difference between CA125 and PFS ( $\mathrm{p}=0.404)$ or OS ( $\mathrm{p}=0.335)$.

\section{Different expression of EOC-related genes in CTCs and tissues}

WT1 and PAX8 are commonly used markers for the diagnosis and identification of ovarian cancer in clinical pathology [30]. To analyze the roles of these genes in CTCs and their relationships with tissues, we compared the expression of WT1 in CTCs with IHC from the corresponding primary tumor in 36 patients, and the expression of PAX8 in CTCs with IHC from the corresponding primary tumor in 43 patients (Table 3 and Fig. 5). Both WT1 and PAX8 were examined in 34 patients. The similarity rate for WT1 between CTCs and tissues was $18 / 36(50 \%)$, while for PAX8 it was $27 / 43$ (63\%), and for both WT1 and PAX8 the similarity rate was $38 \%(13 / 34)$. We then compared the clinical characteristics of patients with different expression patterns in CTCs and tissues (Table 4). However, due to the fact that the number of patients is low, statistically significant differences could not be detected, but a trend for differential expression between tissues and CTCs may be associated with the numbers of circulating tumor cells. 


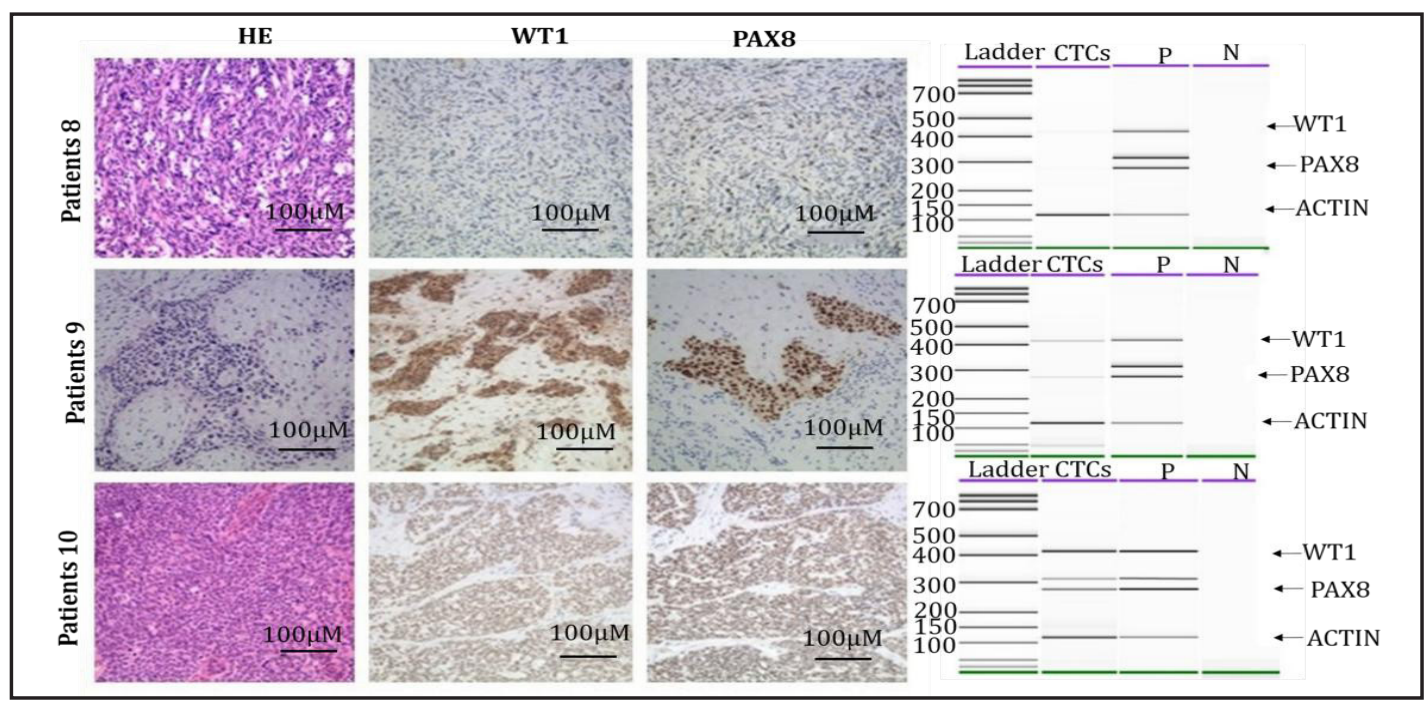

Fig. 5. WT1 and PAX8 expression in CTCs and corresponding primary tumor tissue. Patient 4 was negative for both WT1 and PAX8 in tissue by IHC, and also negative for expression in CTCs. Patient 5 was positive for both WT1 and PAX8 in tissue by IHC, and positive for expression in CTCs. Patient 6 was strong positive for both WT1 and PAX8 in tissue by IHC and had high expression in CTCs. (P=positive control, N=negative control). Original magnification was X20.

Table 4. Expression (CTC+/CTC-) of WT1 and PAX in CTCs and the presence of proteins (IHC+/IHC-) in their correcponding tumors in EOC patients with different clinical characteristic. NOTE: Cell No., CTC numbers from patients; Peritoneum status, metastatic status of the peritoneum

\begin{tabular}{|c|c|c|c|c|c|c|c|c|c|c|}
\hline & \multicolumn{4}{|c|}{ WT1 } & \multicolumn{6}{|c|}{ PAX8 } \\
\hline & $\begin{array}{c}\text { CTC+ } \\
\text { /IHC- } \\
\text { n=9 }\end{array}$ & $\begin{array}{l}\text { CTC+ } \\
/ \text { IHC }+ \\
n=11\end{array}$ & $\begin{array}{c}\text { CTC- } \\
/ \text { IHC+ } \\
\text { n=9 }\end{array}$ & $\begin{array}{c}\text { CTC- } \\
\text { /IHC- } \\
\mathrm{n}=7\end{array}$ & $\begin{array}{c}\mathrm{P} \\
\text { value }\end{array}$ & $\begin{array}{c}\text { CTC+ } \\
/ \text { IHC- } \\
\mathrm{n}=4\end{array}$ & $\begin{array}{c}\text { CTC+ } \\
/ \text { IHC+ } \\
n=25\end{array}$ & $\begin{array}{c}\text { CTC- } \\
/ \text { IHC+ } \\
\mathrm{n}=12\end{array}$ & $\begin{array}{c}\text { CTC- } \\
\text { /IHC- } \\
\mathrm{n}=2\end{array}$ & $P$ value \\
\hline \multirow{4}{*}{$\begin{array}{l}\text { Age Average } \\
\text { Age Range } \\
\text { Cell No. Average } \\
\text { Cell No. Range }\end{array}$} & 57 & 53 & 53 & 53 & \multirow[b]{2}{*}{0.067} & 53 & 53 & 53 & 53 & \multirow[b]{2}{*}{0.221} \\
\hline & $38-76$ & $40-77$ & $48-75$ & $29-55$ & & $49-69$ & $29-77$ & $48-75$ & $32-51$ & \\
\hline & 229 & 265 & 129 & & \multirow[b]{2}{*}{0.389} & 341 & 360 & & & \multirow[b]{2}{*}{0.021} \\
\hline & $\begin{array}{c}3- \\
1148\end{array}$ & $\begin{array}{c}\text { 6- } \\
1172\end{array}$ & $\begin{array}{c}0- \\
1929\end{array}$ & $0-163$ & & $\begin{array}{c}78- \\
1148\end{array}$ & $\begin{array}{c}6- \\
1929\end{array}$ & $\begin{array}{c}02 \\
0-90\end{array}$ & 0 & \\
\hline \multicolumn{11}{|l|}{ Symptom } \\
\hline Yes & 6 & 7 & 8 & 6 & \multirow{2}{*}{0.211} & 4 & 14 & 12 & 2 & \multirow{2}{*}{0.126} \\
\hline No & 3 & 4 & 1 & 1 & & 0 & 11 & 0 & 0 & \\
\hline \multicolumn{11}{|l|}{ CA125 } \\
\hline$\geq 35 \mathrm{U} / \mathrm{ml}$ & 8 & 10 & 7 & 6 & \multirow[t]{3}{*}{0.637} & 3 & 23 & 10 & 2 & \multirow[t]{3}{*}{0.789} \\
\hline$<35 \mathrm{U} / \mathrm{ml}$ & 1 & 1 & 2 & 1 & & 1 & 2 & 2 & 0 & \\
\hline \multicolumn{9}{|l|}{ Ascites } & & \\
\hline Yes & 5 & 7 & 4 & 5 & \multirow[t]{2}{*}{0.794} & 4 & 15 & 6 & 1 & \multirow[t]{2}{*}{0.148} \\
\hline No & 4 & 4 & 5 & 2 & & 0 & 10 & 6 & 1 & \\
\hline Stage I & 2 & 3 & 2 & 3 & \multirow{4}{*}{0.395} & 1 & 6 & 3 & 0 & \multirow{4}{*}{0.176} \\
\hline Stage II & 3 & 0 & 1 & 1 & & 0 & 4 & 2 & 0 & \\
\hline Stage III & 2 & 4 & 5 & 3 & & 0 & 11 & 6 & 2 & \\
\hline Stage IV & 2 & 4 & 1 & 0 & & 3 & 4 & 1 & 0 & \\
\hline \multicolumn{11}{|l|}{ Tumor size } \\
\hline$<5 \mathrm{~cm}$ & 1 & 1 & 1 & 0 & \multirow[t]{2}{*}{0.513} & 0 & 4 & 1 & 0 & \multirow[t]{2}{*}{0.789} \\
\hline$\geq 5 \mathrm{~cm}$ & 8 & 10 & 8 & 7 & & 4 & 21 & 11 & 2 & \\
\hline \multicolumn{11}{|l|}{ Peritoneum status } \\
\hline Yes & 7 & 8 & 7 & 3 & \multirow[t]{2}{*}{0.211} & 3 & 19 & 3 & 2 & \multirow[t]{2}{*}{0.112} \\
\hline No & 2 & 3 & 2 & 4 & & 1 & 6 & 9 & 0 & \\
\hline \multicolumn{11}{|l|}{ Histology } \\
\hline Serous & 7 & 11 & 7 & 2 & & 2 & 22 & 9 & 2 & \\
\hline Mucous & 0 & 0 & 2 & 1 & $\mathrm{~N}$ & 1 & 0 & 2 & 0 & $\mathrm{~N}$ \\
\hline Endometrioid & 0 & 0 & 0 & 0 & & 0 & 0 & 0 & 0 & \\
\hline Clear cell & 2 & 0 & 0 & 4 & & 1 & 3 & 1 & 0 & \\
\hline Grade 1 & 0 & 0 & 1 & 3 & & 0 & 2 & 2 & 0 & \\
\hline Grade 2 & 0 & 1 & 0 & 0 & & 2 & 0 & 1 & 0 & \\
\hline Grade 3 & 9 & 10 & 8 & 4 & $\mathrm{~N}$ & 2 & 23 & 9 & 2 & $\mathrm{~N}$ \\
\hline Lymph node & & & & & & & & & & \\
\hline $\mathrm{N} 1$ & 0 & 4 & 3 & 0 & 0.913 & 1 & 19 & 2 & 1 & 0.181 \\
\hline No & 9 & 7 & 6 & 7 & & 3 & 6 & 9 & 1 & \\
\hline
\end{tabular}




\section{Discussion}

Previous research suggested that metastasis via implantation was the main mechanism for the spread of cancer, and that hematogenous metastasis occurs at a late stage of tumor development [31]. Recently, research has suggested that at least $80 \%$ of metastases are derived from disseminated cancer cells originating from early stage tumors [32]. The presence of CTCs, thus, would predict a worse outcome for patients with non-metastatic breast cancer [33], where ovarian cancer CTCs would form omental metastasis as seen in the mouse [34]. This research indicates that we need to rethink the role of blood metastasis in EOC. Previous research, using an anti-epithelial antibody-enrichment method followed by identification techniques, has been shown to be useful in the detection of CTCs $[35,36]$. Many markers have been applied to the enrichment and screening of ovarian cancer CTC [37]. Liu et al [20]. found the positive rate of CTCs in ovarian cancer patients was $60 \%$ in advanced stage disease using the CellSearch system targeting EpCAM+. Kuhlmann et al [38]. detected CTCs using immunomagnetic CTC enrichment targeting EpCAM and MUC1, followed by RT-PCR to detect EpCAM, MUC1, CA125, and ERCC1 positive cells. Ghazani et al [39]. detected CTCs by $\mu$ NMR system targeting EpCAM, HER2, EGFR, and MUC1. Aktas et al [24]. detected CTCs using immunomagnetic CTC enrichment targeting EpCAM and MUC1, followed by RT-PCR to detect EpCAM, MUC1, HER2, and CA125, where CTCs were detected in $19 \%$ patients before surgery. Based on these previous studies, we selected EpCAM, HER2, and MUC1 for enrichment, and found that the combination of these three antibodies to be best. To confirm the identity of the CTCs we chose the ovarian cancer-related genes EpCAM, HER2, MUC1, WT1, PAX8, and P16, as these six genes have well established roles in ovarian cancer, including diagnosis, drug resistance, and prognosis [28, 30, 40].

Using our method, we found that we could identify CTCs in 90\% (98 of 109) newly diagnosed EOC patients, while a similar percentage $(91 \%, 100 / 109)$ were positive for CA125. For early stage disease, we detected CTCs in about 83\% (30/36) of the patients, with the strongest distinction with CA125 found in 14 patients with early stage (stage IA-IB) disease with capsule integrity and having no pelvic cavity metastasis, where CTC detection rate was $93 \%$ while CA125 was only $64 \%$. Since CTCs were more prominent than CA125 in early stage disease, this suggests that hematogenous metastasis of ovarian cancer might be earlier than peritoneal metastasis.

At present, clinical treatment of ovarian cancer patients is divided into two types: nonneoadjuvant chemotherapy and neoadjuvant chemotherapy. Most patients accept nonneoadjuvant chemotherapy treatment, while patients with extensive tumors metastases are provided with neoadjuvant chemotherapy. Our study found that the numbers of CTCs increased significantly after surgery for both types of treatment methods. During operations, the rupture of blood vessels and other factors might lead to the release of a large number of tumor cells into the blood that account for the above observations, while chemotherapy, leading to the death of tumor cells, decreases the number of circulating tumor cells. The expression of EpCAM and HER2 in CTCs at the time of diagnosis was positively correlated with resistance to chemotherapy. Obermayr et al [18]., through the analysis of the expression of markers genes including PPIC by qRT-PCR, found that CTCs occurred more often in platinum resistant patients, and that significantly increased numbers of PPIC positive CTCs were found during the follow-up of platinum resistant tumors compared to platinum sensitive patients. Kuhlmann et al [38]. found that the presence of ERCC1-positive CTC at primary diagnosis was likewise to be an independent predictor of platinum resistance. However, our results are inconsistent with some other research. Woopen et al [41]. assessed the expression of EpCAM by immunohistochemistry on primary EOC tissue samples, and found that overexpression of EpCAM is associated with a more favorable response to platinum-based chemotherapy. The appearance of this phenomenon may be related to the genetic changes of tumor cells after blood transfusion.

Moreover, we found that the expression of EpCAM and HER2 was higher in patients that died during follow-up compared to those that had survived. OS was significantly shorter in 


\section{Cellular Physiology Cell Physiol Biochem 2018;48:1983-1994

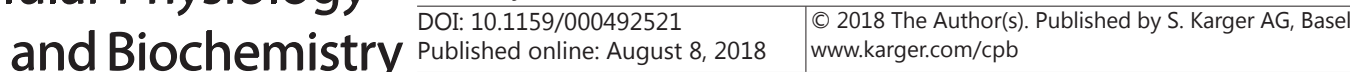 \\ Zhang et al.: CTCs as a Biomarker in Ovarian Cancer}

patients with CTCs positive for EpCAM compared to EpCAM negative patients. A significant decline in CA125 levels after treatment has not been associated with prognosis, and this might indicate that the detection of CTC is the real predictor of prognosis in patients. Poveda et al [42]. indicated that elevated numbers of CTCs impact an unfavorable prognosis for ovarian cancer patients using the CellSearch system. Aktas et al [24]. found that presence of CTC is significantly positively correlated with shorter OS using the AdnaTest BreastCancer. But some others have not found similar results. Liu et al [20]. found that CTC numbers does not correlate significantly with patient outcomes using the CellSearch system. Judson et al [19]. found that survival curves did not differ between patients with and without CTCs detected by a tumor-enriched immunocytochemical assay targeted to CK20, EGFR, CK8, CK18, and TFS-2. For tissues, there is still a controversy about the relationship between expression of EpCAM and prognosis in ovarian cancer, some of which are consistent with our conclusions. Spizzo et al [43]. indicated that EpCAM overexpression was significantly related to decrease OS through immunohistochemistry, but Battista et al [44]. support the hypothesis that the expression of EpCAM is associated with favorable prognosis using data generated by immunohistochemistry.

Based on the above results, we found that ovarian cancer CTCs are indeed associated with the diagnosis and prognosis of ovarian cancer. But what are the similarities between CTCs and primary tumors tissues? Studies have investigated the similarities and differences between CTCs and primary tumors [13]. We found that CTCs may be the same or different from primary tumor tissue, but we failed to reach a conclusion as we had few samples, thus, in the future we need to increase our sample size to identify the relevant factors explaining the differences between tissues and CTCs.

In conclusion, CTCs can be detected at all stages of EOC disease in patients, and through the detection of CTC, and their gene expression patterns, we can predict the likelihood of chemotherapy resistance and judge prognosis. For early diagnosis and monitoring of treatment effect on tumors there is still a very long way to go, although CTCs are potentially a more effective and convenient approach. Additional assays aimed at additional and new specific markers, and the screening of disease-free people, is required.

\section{Acknowledgements}

This study was supported by grants from the National Natural Science Foundation of China (NSFC) Grant Number 81673459; National Key Technologies R\&D Program (Grant Numbers 2012BAK25B01, 2015BAK45B01), and a grant from the National Science Foundation of China - Canadian Institutes of Health Research (NSFC-CIHR) China-Canada Joint Health Research Initiative (Grant Numbers 81061120525 and CCI-109605).

\section{Disclosure Statement}

The authors declare no conflict of interests.

\section{References}

1 Cannistra SA: Cancer of the ovary. N Engl J Med 2004;351:2519-2529.

-2 Chen W, Zheng R, Baade PD, Zhang S, Zeng H, Bray F, Jemal A, Yu XQ He J: Cancer statistics in China, 2015. CA Cancer J Clin 2016;66:115-132.

3 Bowtell DD: The genesis and evolution of high-grade serous ovarian cancer. Nat Rev Cancer 2010;10:803808.

4 Baldwin LA, Huang B, Miller RW, Tucker T, Goodrich ST, Podzielinski I, DeSimone CP, Ueland FR, van Nagell JR, Seamon LG: Ten-year relative survival for epithelial ovarian cancer. Obstet Gynecol 2012;120:612-618. 


\section{Cellular Physiology Cell Physiol Biochem 2018;48:1983-1994 \begin{tabular}{ll|l} 
and Biochemistry Published online: August 8, 2018 & $\begin{array}{l}\text { (c) } 2018 \text { The Author(s). Published by S. Karger AG, Basel } \\
\text { www.karger.com/cpb }\end{array}$
\end{tabular} \\ Zhang et al.: CTCs as a Biomarker in Ovarian Cancer}

5 Jung JG, Shih IM, Park JT, Gerry E, Kim TH, Ayhan A, Handschuh K, Davidson B, Fader AN, Selleri L, Wang TL: Ovarian Cancer Chemoresistance Relies on the Stem Cell Reprogramming Factor PBX1. Cancer Res 2016;76:6351-6361.

6 Jacobs IJ, Menon U: Progress and challenges in screening for early detection of ovarian cancer. Mol Cell Proteomics 2004;3:355-366.

-7 Felder M, Kapur A, Gonzalez-Bosquet J, Horibata S, Heintz J, Albrecht R, Fass L, Kaur J, Hu K, Shojaei H, Whelan RJ, Patankar MS: MUC16 (CA125): tumor biomarker to cancer therapy, a work in progress. Mol Cancer 2014;13:129.

-8 Zhang W, Xia W, Lv Z, Ni C, Xin Y, Yang L: Liquid Biopsy for Cancer: Circulating Tumor Cells, Circulating Free DNA or Exosomes? Cell Physiol Biochem 2017;41:755-768.

-9 Lai X, Wang M, McElyea SD, Sherman S, House M, Korc M: A microRNA signature in circulating exosomes is superior to exosomal glypican-1 levels for diagnosing pancreatic cancer. Cancer Lett 2017;393:86-93.

10 Alix-Panabieres C, Pantel K: Circulating tumor cells: liquid biopsy of cancer. Clin Chem 2013;59:110-118.

11 Nguyen DX, Bos PD, Massague J: Metastasis: from dissemination to organ-specific colonization. Nat Rev Cancer 2009;9:274-284.

12 Aguirre-Ghiso JA, Bragado P, Sosa MS: Metastasis awakening: targeting dormant cancer. Nat Med 2013;19:276-277.

13 O'Flaherty L, Wikman H, Pantel K: Biology and clinical significance of circulating tumor cell subpopulations in lung cancer. Transl Lung Cancer Res 2017;6:431-443.

14 Markou A, Lazaridou M, Paraskevopoulos P, Chen S, Swierczewska M, Budna J, Kuske A, Gorges TM, Joosse SA, Kroneis T, Zabel M, Sedlmayr P, Alix-Panabieres C, Pantel K, Lianidou ES: Multiplex Gene Expression Profiling of In vivo Isolated Circulating Tumor Cells in High-Risk Prostate Cancer Patients. Clin Chem 2017;64:297-306.

15 Politaki E, Agelaki S, Apostolaki S, Hatzidaki D, Strati A, Koinis F, Perraki M, Saloustrou G, Stoupis G, Kallergi G, Spiliotaki M, Skaltsi T, Lianidou E, Georgoulias V, Mavroudis D: A Comparison of Three Methods for the Detection of Circulating Tumor Cells in Patients with Early and Metastatic Breast Cancer. Cell Physiol Biochem 2017;44:594-606.

-16 Yu C, Wang Z, Xu X, Xiang W, Huang X: Circulating Hepatocellular Carcinoma Cells are Characterized by CXCR4 and MMP26. Cell Physiol Biochem 2015;36:2393-2402.

17 Liu H, Sun B, Wang S, Liu C, Lu Y, Li D, Liu X: Circulating Tumor Cells as a Biomarker in Pancreatic Ductal Adenocarcinoma. Cell Physiol Biochem 2017;42:373-382.

18 Obermayr E, Castillo-Tong DC, Pils D, Speiser P, Braicu I, Van Gorp T, Mahner S, Sehouli J, Vergote I, Zeillinger R: Molecular characterization of circulating tumor cells in patients with ovarian cancer improves their prognostic significance - a study of the OVCAD consortium. Gynecol Oncol 2013;128:15-21.

19 Judson PL, Geller MA, Bliss RL, Boente MP, Downs LS, Jr., Argenta PA, Carson LF: Preoperative detection of peripherally circulating cancer cells and its prognostic significance in ovarian cancer. Gynecol Oncol 2003;91:389-394.

-20 Liu JF, Kindelberger D, Doyle C, Lowe A, Barry WT, Matulonis UA: Predictive value of circulating tumor cells (CTCs) in newly-diagnosed and recurrent ovarian cancer patients. Gynecol Oncol 2013;131:352-356.

-21 van der Gun BT, de Groote ML, Kazemier HG, Arendzen AJ, Terpstra P, Ruiters MH, McLaughlin PM, Rots MG: Transcription factors and molecular epigenetic marks underlying EpCAM overexpression in ovarian cancer. Br J Cancer 2011;105:312-319.

-22 Cai Y, Wang J, Zhang L, Wu D, Yu D, Tian X, Liu J, Jiang X, Shen Y, Zhang L, Ren M, Huang P: Expressions of fatty acid synthase and HER2 are correlated with poor prognosis of ovarian cancer. Med Oncol 2015;32:391.

23 Singh AP, Senapati S, Ponnusamy MP, Jain M, Lele SM, Davis JS, Remmenga S, Batra SK: Clinical potential of mucins in diagnosis, prognosis, and therapy of ovarian cancer. Lancet Oncol 2008;9:1076-1085.

24 Aktas B, Kasimir-Bauer S, Heubner M, Kimmig R, Wimberger P: Molecular profiling and prognostic relevance of circulating tumor cells in the blood of ovarian cancer patients at primary diagnosis and after platinum-based chemotherapy. Int J Gynecol Cancer 2011;21:822-830.

25 Nonaka D, Chiriboga L, Soslow RA: Expression of pax8 as a useful marker in distinguishing ovarian carcinomas from mammary carcinomas. Am J Surg Pathol 2008;32:1566-1571.

-26 Heidarpour M, Tavanafar Z: Diagnostic utility of PAX8 in differentiation of mullerian from non-mullerian tumors. Adv Biomed Res 2014;3:96. 


\section{Cellular Physiology Cell Physiol Biochem 2018;48:1983-1994 \begin{tabular}{l|l|l} 
DOI: 10.1159/000492521 & and Biochemistry Published online: August 8, 2018 & $\begin{array}{l}\text { O 2018 The Author(s). Published by S. Karger AG, Basel } \\
\text { www.karger.com/cpb }\end{array}$
\end{tabular} \\ Zhang et al.: CTCs as a Biomarker in Ovarian Cancer}

27 Liu Z, Yamanouchi K, Ohtao T, Matsumura S, Seino M, Shridhar V, Takahashi T, Takahashi K, Kurachi H: High levels of Wilms' tumor 1 (WT1) expression were associated with aggressive clinical features in ovarian cancer. Anticancer Res 2014;34:2331-2340.

28 Nazlioglu HO, Ercan I, Bilgin T, Ozuysal S: Expression of p16 in serous ovarian neoplasms. Eur J Gynaecol Oncol 2010;31:312-314.

29 Silverberg SG: Histopathologic grading of ovarian carcinoma: a review and proposal. Int J Gynecol Pathol 2000;19:7-15.

-30 Liliac L, Carcangiu ML, Canevari S, Caruntu ID, Ciobanu Apostol DG, Danciu M, Onofriescu M, Amalinei C: The value of PAX8 and WT1 molecules in ovarian cancer diagnosis. Rom J Morphol Embryol 2013;54:1727.

-31 Yeung TL, Leung CS, Yip KP, Au Yeung CL, Wong ST, Mok SC: Cellular and molecular processes in ovarian cancer metastasis. A Review in the Theme: Cell and Molecular Processes in Cancer Metastasis. Am J Physiol Cell Physiol 2015;309:C444-456.

-32 Hosseini H, Obradovic MM, Hoffmann M, Harper KL, Sosa MS, Werner-Klein M, Nanduri LK, Werno C, Ehrl C, Maneck M, Patwary N, Haunschild G, Guzvic M, Reimelt C, Grauvogl M, Eichner N, Weber F, Hartkopf AD, Taran FA, Brucker SY, et al.: Early dissemination seeds metastasis in breast cancer. Nature 2016;540:552558.

33 Lucci A, Hall CS, Lodhi AK, Bhattacharyya A, Anderson AE, Xiao L, Bedrosian I, Kuerer HM, Krishnamurthy S: Circulating tumour cells in non-metastatic breast cancer: a prospective study. Lancet Oncol 2012;13:688695.

-34 Pradeep S, Kim SW, Wu SY, Nishimura M, Chaluvally-Raghavan P, Miyake T, Pecot CV, Kim SJ, Choi HJ, Bischoff FZ, Mayer JA, Huang L, Nick AM, Hall CS, Rodriguez-Aguayo C, Zand B, Dalton HJ, Arumugam T, Lee HJ, Han HD, et al:: Hematogenous metastasis of ovarian cancer: Rethinking mode of spread. Cancer Cell 2014;26:77-91.

35 Lang JM, Casavant BP, Beebe DJ: Circulating tumor cells: getting more from less. Sci Transl Med 2012;4:141ps113.

36 Kallergi G, Politaki E, Alkahtani S, Stournaras C, Georgoulias V: Evaluation of Isolation Methods for Circulating Tumor Cells (CTCs). Cell Physiol Biochem 2016;40:411-419.

37 Cui L, Kwong J, Wang CC: Prognostic value of circulating tumor cells and disseminated tumor cells in patients with ovarian cancer: a systematic review and meta-analysis. J Ovarian Res 2015;8:38.

-38 Kuhlmann JD, Wimberger P, Bankfalvi A, Keller T, Scholer S, Aktas B, Buderath P, Hauch S, Otterbach F, Kimmig R, Kasimir-Bauer S: ERCC1-positive circulating tumor cells in the blood of ovarian cancer patients as a predictive biomarker for platinum resistance. Clin Chem 2014;60:1282-1289.

-39 Ghazani AA, Castro CM, Gorbatov R, Lee H, Weissleder R: Sensitive and direct detection of circulating tumor cells by multimarker micro-nuclear magnetic resonance. Neoplasia 2012;14:388-395.

40 Deng J, Wang L, Chen H, Li L, Ma Y, Ni J, Li Y: The role of tumour-associated MUC1 in epithelial ovarian cancer metastasis and progression. Cancer Metastasis Rev 2013;32:535-551.

41 Woopen H, Pietzner K, Richter R, Fotopoulou C, Joens T, Braicu EI, Mellstedt H, Mahner S, Lindhofer H, Darb-Esfahani S, Denkert C, Sehouli J: Overexpression of the epithelial cell adhesion molecule is associated with a more favorable prognosis and response to platinum-based chemotherapy in ovarian cancer. J Gynecol Oncol 2014;25:221-228.

42 Poveda A, Kaye SB, McCormack R, Wang S, Parekh T, Ricci D, Lebedinsky CA, Tercero JC, Zintl P, Monk BJ: Circulating tumor cells predict progression free survival and overall survival in patients with relapsed/ recurrent advanced ovarian cancer. Gynecol Oncol 2011;122:567-572.

43 Spizzo G, Went P, Dirnhofer S, Obrist P, Moch H, Baeuerle PA, Mueller-Holzner E, Marth C, Gastl G, Zeimet AG: Overexpression of epithelial cell adhesion molecule (Ep-CAM) is an independent prognostic marker for reduced survival of patients with epithelial ovarian cancer. Gynecol Oncol 2006;103:483-488.

44 Battista MJ, Cotarelo C, Jakobi S, Steetskamp J, Makris G, Sicking I, Weyer V, Schmidt M: Overexpression of epithelial cell adhesion molecule protein is associated with favorable prognosis in an unselected cohort of ovarian cancer patients. J Cancer Res Clin Oncol 2014;140:1097-1102. 